\title{
The Impact of Financial Crises on the Environment in Developing Countries*
}

\author{
João Tovar Jalles ${ }^{\#}$
}

December 2019

\begin{abstract}
This paper evaluates empirically the effect of financial crises on several types of pollutant emissions. We focus on a sample of 55 developing countries from 1980 until 2012 and rely on the local projection method to plot impulse response functions. Our results show that financial crises lead to a fall in $\mathrm{CO} 2$ emissions. Moreover, systemic crises increase consumption-based emissions, which suggests that this type of crises encourages the consumption of goods with an inferior environmental quality. A country hit by a sovereign debt crisis, experiences an increase in emissions stemming from energy related activities or industrial processes. During bad times, financial crises positively affect both methane and nitrous oxide emissions. Finally, in countries under fiscal retrenchment, a financial crisis leads to a negative response of $\mathrm{CO} 2$ emissions.
\end{abstract}

Keywords: greenhouse emissions, $\mathrm{CO} 2$, local projection, impulse response function, recessions, fiscal contractions.

JEL codes: E32, E6, F65, G01, O44, Q54

\footnotetext{
* The author is grateful to the editor and one anonymous referee for useful comments and suggestions on an earlier version of the paper. Thanks also go to Prakash Loungani for useful discussions. The usual disclaimer applies and any remaining errors are the author's sole responsibility.

\# ISEG- University of Lisbon and REM/UECE, Rua Miguel Lupi 20, 1249-078 Lisbon, Portugal; Centre for Globalization and Governance and Economics for Policy, Nova School of Business and Economics, Rua da Holanda, 1, 2775-405 Carcavelos, Portugal; email: joaojalles@gmail.com
} 


\section{Introduction}

The Global Financial Crisis (GFC) and to the Great Recession that followed, reopened the policy discussion on the compatibility between economic growth and environmental sustainability. The fall in production as a result of the crisis, led to downward adjustments in consumption and investment patterns and, consequently, to reductions in energy consumption and, thus, carbon dioxide emissions. ${ }^{1}$ However, there was no significant change in the global temperature trend, on the contrary (Enkvist et al., 2010). More importantly, in contrast with the oil crises of the 1970s, the GFC did not lead to a structural change in the growth path of emissions in the recent recovery years (Peters et al., 2011). ${ }^{2}$ After a mild decline of 1.4 percent in 2009, in 2010 a 3 percent growth was already observed in global CO2 emissions, followed by 2.2 percent in 2012, and 2.3 percent in 2013 (The Global Carbon Project). Additionally, global carbon dioxide emissions reached an all-time high in $2011 .^{3}$ This fact escalated the number of debates on how the GFC may had impacted climate change policies (Egenhoffer, 2008). On the one hand, falls in emissions often incite claims from climate sceptics that worries over global warming are overstated. On the other, a rise in emissions raises concerns among environmental groups that insufficient action is being deployed to address the problem. ${ }^{4}$ In this context, the 2015 Paris climate accord - the so-called

\footnotetext{
${ }^{1}$ The assessment of the output-emissions decoupling hypothesis has been done by several authors (e.g. Kristrom and Lundgren (2005) for Sweden; Ajmi et al. (2015) for G7 countries; Doda (2014) for 81 countries; Cohen et al. (2018) for the top 20 emitters). Others have focused on the validity testing of the so-called Environmental Kuznets Curvesee, e.g., Stern (2004) and Kaika and Zervas (2013).

${ }^{2}$ The authors compare this effect to the effect on emissions after the oil crises in 1973 and 1979 which led to a permanent shift from oil to natural gases and meant a decrease in emissions. In contrast, the Asian financial crisis also led to a drop in global $\mathrm{CO} 2$ emissions that lasted post-crisis as a result of economic and political changes.

${ }^{3}$ This relatively uncharacteristic bounce back in emissions can be attributed to: (1) the globally coordinated action of central banks and initial fiscal stimulus; (2) the immediate easing of energy prices reducing pressure for structural changes in energy consumption; (3) the continuing and accelerated increase in coal-fired power (IEA, 2013).

${ }^{4}$ For instance, a rise in German emissions in 2016 led to alarm in some circles that the country had "further dented" its chances of reaching its 2020 climate targets (Wettengel, 2016).
} 
COP21 - was a landmark effort on the part of countries to set and monitor commitments to mitigate global warming. ${ }^{5}$ Later, the COP23 in 2017 in Bonn "sought to maintain the global momentum to decouple output from greenhouse gas emissions" (Gough, 2017).

We empirically evaluate the impact of (financial) crises on emissions in a panel of 55 emerging and low-income countries between 1980 and 2012. By means of Jorda's (2005) local projection method, we estimate several impulse responses and trace the short to medium-term impact of crises on emissions. A perusal of the literature shows no such systematic and comprehensive study looking specifically at developing countries and exploring the nature of crises and types of emissions considered here. Our make several contributions to the literature. First, we inspect at the role played by different financial crises (systematic, non-systematic, banking, currency or debt) on a variety of emissions split either by sector of activity or gas nature. Moreover, we internalize the international trade component of emissions's spillovers in addressing the crises-emissions relationship. International trade "gives a mechanism for consumers to shift environmental pollution to distant lands" (Peters and Hertwich, 2008). Jaunky (2011) notes that it is possible that although advanced countries "may have experienced a change in their production structure, their consumption structure remains unchanged"; hence, the decoupling may arise simply be because "dirty industries in developed countries tend to migrate" to developing countries. ${ }^{6}$ To account for this aspect, we differentiate between production-based and

\footnotetext{
${ }^{5}$ Leichenko et al. (2010) used the GFC as an example of the close linkage between globalization and climate change. Amann et al. (2009) provide estimates of greenhouse gas mitigation potentials and costs in different countries. They employ the IIASA's Greenhouse gas-Air pollution Interactions and Synergies (GAINS) model. These types pf models have been applied before to identify cost-effective air pollution control strategies, and to study the co-benefits between greenhouse gas mitigation and air pollution control in Europe and Asia (Hordijk and Amann, 2007; Tuinstra, 2007). ${ }^{6}$ According to Giedraitis et al. (2010), the regional differences in the relationship between economic activity and CO2 emissions can partly be explained by the different marginal costs of reducing pollution. For industrial intensive economies the marginal costs of pollution reduction are much higher than for service-oriented economies. Combining this with the displacement effect (Stern, 2004; Jaunky, 2011) advanced countries can more easily lower emissions by displacing polluting intensive production to emerging and low income economies.
} 
consumption-based greenhouse gases emissions, where the latter add in the emissions embodies in the net exports of countries. Second, we control for the prevailing macroeconomic and fiscal conditions at the time of the crisis in affecting the response of emissions. Third, we make use of recent econometric techniques with several advantages relative to alternative approaches.

We find that financial crises result if a decrease of $\mathrm{CO} 2$ emissions. Moreover, systemic crises positively impact consumption-based emissions, suggesting that, on average, this type of crises encouraged the consumption of goods with an inferior environmental quality. A country that is hit by a debt crisis will experience an increase in emissions stemming from either energy related activities or industrial processes. Splitting the sample by income group, we find that, in normal times, financial (debt) crises lead to in a fall in $\mathrm{CO} 2$ (production-based GHG) emissions in emerging markets. For low-income countries, we observe a positive (negative) and statistically significant response of methane emissions following banking (currency) crises. In bad times, financial crises positively affect both methane and nitrous oxide emissions. In contrast, during periods of economic expansions, the effects tend to be negative but are most of the time imprecisely estimated. During periods of fiscal retrenchment, a financial crisis results in a fall in $\mathrm{CO} 2$ emissions. Finally, $\mathrm{CO} 2$ emissions respond positively (negatively) after a banking or debt crisis that takes place simultaneously with a loosening (tightening) of the fiscal stance.

The paper is organized as follows. Section 2 reviews the literature. Section 3 describes our data and Section 4 discusses the empirical approach. Section 5 presents our main results and the Section 6 concludes. 


\section{Literature Review}

The major greenhouse gas - carbon dioxide - has been shown to move in tandem with the economy and to be strongly correlated with both GDP and energy consumption (Gierdraitis et al. (2010) and Lane (2011). The analysis of the 1870s and 1930s depressions by Giedraitis et al. (2010) and, more recently, by Stavytskyy et al. (2016) support the claim that economic crises are associated with lower CO2 emissions. Inspecting the Asian Financial Crisis, Siddiqi (2000) alluded to some positive consequences stemming from it to the global environment. York (2012) demonstrated that the response of emissions to an increase in income was greater during good times than during bad times. Sobrino and Monzon (2014) assessed the environmental effects of the Global Financial Crisis in Spain and found that it led to a fall of transport activity and to higher road energy efficiency. Declercq et al. (2014), who investigated the impact of recessions on CO2 emissions in the European power sector from 2008 to 2009, argued that the lower demand for electricity during recessionary times was the most important factor in mitigating $\mathrm{CO} 2$ emissions.

Notwithstanding, these studies mix the short and the long-term implications of financial crises for the environment. For some, despite short-term reductions in emissions in crisis years, economic crises are typically not good for the environment. The main argument is that, contrary to what many would expect, recessions, by making access to capital more difficult, negatively affect emissions reduction efforts through their discouraging effects on investments (including investments in low-carbon technologies) (Del Río and Labandeira, 2009). As both governments and the private sector focus on the recovery and on adapting their respective budgets, are shifted away from climate policies. As a result, crises lead to postponement of environmental projects as surviving the crisis becomes the goal, rather than transitionary at that time to a "green" company 
or economy. Also, at a time of economic crisis, carbon lock-in is much more likely. ${ }^{7}$ Depressed aggregate demand, the fall in the prices of some goods and lower economic capacity encourage the consumption of goods with a lower environmental quality (typically cheaper) and to an overexploitation of resources with associated environmental degradation effects (Del Río and Labandeira, 2009). Additionally, lower energy prices during crises, reduce the economic viability of cleaner technologies. Governments are likely to avoid burdening businesses with extra costs and regulation at a time when the economy is fragile and jobs may be at risk (Wooders and Runnalls, 2008). Such scenarios also assume a low political will to implement climate policy in the short term and a reduced incentive to participate in international agreements to tackle the issue in the longer term.

In contrast, another group of people advocate exactly the opposite that economic crises provide an opportunity for developing and investing in low-carbon technologies that, in turn, could provide a way out of the recession (Greenpeace, 2008). According to this view, given the long lifetime of most energy infrastructures and technologies, the opportunities provided by crises to replace carbon-intensive technologies by cleaner alternatives should not be missed. For Papandreou (2015), crises can open up opportunities for new institutional pathways if the forces they unleash or the rebalancing of conflicting political and economic interests give rise to changes in existing norms and institutions. ${ }^{8}$ Crises throw existing institutions, governance structures and

\footnotetext{
${ }^{7}$ Carbon lock-in refers to the difficulty to shift the economy and technological systems into a low-carbon path. Whereas traditional economic approaches emphasize the role of existing physical infrastructures and the long age of the capital stock in key sectors (energy production and transport), more recent "evolutionary" approaches consider a wide array of sources of carbon lock-in, including economic and non-economic barriers to changes in complex technological systems (Unruh, 2000; Marechal, 2007).

${ }^{8}$ Acemoglu and Robinson (2012) provide a sweeping account of the development of nations over millennia and how different crises or historical contingencies were often turning points that could substantially alter the trajectory of a country, locking them into a virtuous cycle of prosperity or sometimes having the opposite effect.
} 
theories that legitimize them into new critical light. ${ }^{9}$ Given the greater competition on scarce resources and short-term priorities for the use of those resources, crises should strengthen the case for a suitable design of climate policies which lead to cost-effective emissions reductions in an intertemporal perspective. Proponents of this view call for clear, long-term and stable policy frameworks and more collaboration at the international level.

\section{Empirical Methodology}

We estimate and trace out the average evolution of emissions to different types of crises. The approach followed is the one by Jordà (2005). This approach to estimate impulse-response functions has been advocated by Auerbach and Gorodnichencko (2013) and Romer and Romer (2017)as a flexible alternative to vector autoregressions (autoregressive distributed lag models) since it does not impose dynamic restrictions. It is also suited to estimating nonlinearities in the dynamic response.

The baseline specification takes the following form:

$y_{i, t+k}-y_{i, t-1}=\alpha_{i}+\mu_{t}+\beta_{k} F C_{i, t}+\theta \mathrm{X}_{i, t}+\varepsilon_{i, t}$

in which $y_{i, t+k}$ is the natural logarithm of an emissions variable (see section 4 for details) in country $i$ in period $t+k ; \alpha_{i}$ are country fixed effects included to control for unobserved cross-country heterogeneity; $\mu_{t}$ are time effects to control to control for global shocks; $F C_{i, t}$ is our financial crisis

\footnotetext{
${ }^{9}$ Geels (2013) frames the relationship between the financial crises and sustainability transitions within a multi-level perspective (see also Geels 2002; Van Bree, Verbong, and Kramer, 2010).
} 
variable, which takes value 0 in non-crisis years and 1 in crisis years. $F C_{i, t}$ takes the value of 1 for the starting year of a given financial crisis and 0 otherwise (we focus only on the first year of a given crisis episode to improve the identification and minimize reverse causality problems - as in Ball, Furceri, Leigh, Loungani, 2013). $\mathrm{X}_{i, t}$ is a set of controls including two lags of the dependent variable, two lags of the crisis variable and two lags of real GDP growth (these were chosen based on the Akaike information criterion, but adding more lags does not qualitatively change the thrust of the results). $\varepsilon_{i, t}$ is an i.i.d. disturbance term satisfying standard assumptions of zero mean and constant variance.

In the second specification, the dynamic response varies with the economic business cycle as follows:

$y_{i, t+k}-y_{i, t-1}=\alpha_{i}+\mu_{t}+\beta_{k}^{L} F\left(z_{i, t}\right) F C_{i, t}+\beta_{k}^{H}\left(1-F\left(z_{i, t}\right)\right) F C_{i, t}+\theta M_{i, t}+\varepsilon_{i, t}$

with

$$
F\left(z_{i t}\right)=\frac{\exp \left(-\gamma z_{i t}\right)}{1+\exp \left(-\gamma z_{i t}\right)}, \quad \gamma>0
$$

in which $z_{i t}$ is an indicator of the state of the economy normalized to have zero mean and unit variance. Following Auerbach and Gorodichenko (2012), the indicator of the state of the economy is the real GDP growth rate, and $F_{i t}$ is a smooth transition function used to estimate the environmental impact of crises in expansions versus recessions. They set $\gamma=1.5$, which we also use. Our robustness exercises will include re-estimations based on an alternative measure of economic slack, namely the output gap computed via the recent Hamilton (2018) filter. $M$ is the same set of control variables used in the baseline specification, but now including also two lags of 
$F\left(z_{i, t}\right)$. Equations (1) and (2) are estimated using OLS for each $\mathrm{k}=0, \ldots, 6$. Impulse response functions are computed using the estimated coefficients $\beta_{k}$, and the confidence bands associated with the estimated impulse-response functions are obtained using the estimated standard errors of the coefficients $\beta_{k}$, based on robust standard errors clustered at the country level.

The specification given by equation (2) is equivalent to Granger and Terävistra's (1993) smooth transition autoregressive model. Its advantage is twofold. First, compared with a model in which each dependent variable would be interacted with a measure of the business cycle position, it allows a direct test of whether the effect of crises varies across different regimes. Second, compared with estimating structural vector autoregressions for each regime it allows the effect of crises to change smoothly between good and bad times by considering a continuum of states to compute the impulse response functions, thus making the response more stable and precise.

\section{Data and Stylized Facts}

\subsection{Emissions}

Data was aggregated by the World Resources Institute (WRI), which includes GHG emissions by gas and economic sectors. GHG emissions rely on a gas aggregation method that includes carbon dioxide $(\mathrm{CO} 2)$ and non- $\mathrm{CO} 2$ emissions, such as methane $(\mathrm{CH} 4)$, nitrous oxide $(\mathrm{N} 2 \mathrm{O})$, and fluorinated gases (F-gases), converted based on their 100-year Global Warming Potential (GWP100) according to the IPCC's 2nd Assessment Report. We do not include GHG emissions from 
Land-use and Land-use Change and Forestry (LULUCF) in our baseline results, given the discrepancies between FAO data and what countries report to the UNFCCC. ${ }^{10}$

$\mathrm{CO} 2$ emissions from fossil fuel combustion and cement manufacture are available from the International Energy Agency (IEA) for 101 developing economies, the Carbon Dioxide Information Analysis Center (CDIAC) for 50 countries that lack IEA data (cover mostly cement production and up to 2011), and the U.S. Energy Information Administration (USEIA), which complements the CDIAC's 2012 emissions for the 50 countries that lack IEA data.

CH4 and N2O are taken from U.S. Environmental Protection Agency (US-EPA), which provides data on emissions from industrial processes and waste, and from the Food and Agriculture Organization (FAO), which includes data on agriculture emissions. Fluorinated gas emissions are provided by the US-EPA and fall within the industrial processes sector.

Emissions by economic sector regroup agriculture, energy, industrial processes, and waste emissions. Agriculture emissions are made of $\mathrm{CH} 4$ and $\mathrm{N} 2 \mathrm{O}$ (data from FAO) and energy emissions are composed of $\mathrm{CO} 2$ from fuel combustion (IEA) and of $\mathrm{CH} 4$ and $\mathrm{N} 2 \mathrm{O}$ from fugitive emissions (US-EPA). Industrial processes include CO2 from cement production (CDIAC) and other related emissions (US-EPA), and waste emissions are produced by $\mathrm{CH} 4$ and N2O from landfills and human sewage (US-EPA).

With the exception of CO2 for which we have longer time series - starting in 1980 - all other emission series begin in 1990. CO2 produces eight times less greenhouse effects than methane. However, with a focus on the concentration, among Carbone dioxide, methane and

\footnotetext{
${ }^{10}$ Our results are robust even with the inclusion of LULUCF - see the Appendix Figure A0. That said, Nitrous oxide and, to a large degree, methane are emitted by activities related to agriculture (we thank an anonymous referee for this comment). We estimated the baseline regression for financial crises adding up to two lags of the value-added in agriculture in percent of GDP (from the World Bank's WDI) and while the IRF for nitrous oxide lost a bit of statistical significance at the end of the horizon, results remain qualitatively unchanged for methane.
} 
nitrous oxide, the $\mathrm{CO} 2$ has the biggest impact on global warming. Moreover, whereby methane naturally breaks down relatively quickly in the atmosphere, the lifespan of $\mathrm{CO} 2$ exceeds the first one. As a result, in order to further inspect the relevance of financial crises in affecting $\mathrm{CO} 2$ emissions, we resort to IEA categorization into $\mathrm{CO} 2$ stemming from electricity and gas, from manufacturing, from transportation and from other fuel combustion. These series also go back to 1980.

The previously described GHG emissions variable is what we will refer to as "productionbased" emissions. Now, to compute our "consumption-based" GHG emissions counterpart, we require a measure of emissions embodied in international trade. We use the Eora multi-region input-output (MRIO) database, which provides data on both production and consumption emissions. The database matches emissions with input output tables covering more than 15,000 sectors and 170 countries of our original dataset. Production-based emissions are based on EDGAR (Emissions Database for Global Atmospheric Research) and FAO. EDGAR's CO2, CH4, and $\mathrm{N} 2 \mathrm{O}$ emissions are calculated based on the energy balance statistics of the IEA, which is the same source of emissions as for the WRI dataset, agriculture emissions follow FAO, and the remaining emissions combine alternative sources. In light of some differences in production emissions from Eora and our original emissions time series, we use the difference between Eora's consumption and production emissions, capturing emissions derived from international trade and added it to our production-based emissions for each country and year.

\subsection{Financial Crises and Other Data}

Financial crisis dummies are retrieved from Leaven and Valencia's (2010) publicly available database. These include overall financial crises, systemic and non-systemic crises, banking crises, 
currency crises and, finally, debt crises. These authors provide detailed information on the starting date of several types of crises. The dataset is constructed by combining quantitative indicators measuring e.g. banking sector distress, such as a sharp increase in nonperforming loans and bank runs, with a subjective assessment of the situation. The database documents many features of several banking crises episodes from 1980 to 2012, including details on the resolution policy interventions put in place to attenuate the distress of the banking sector. Their database extends and builds on the database of Caprio et al. (2005).

As far as macroeconomic variables are concerned, real GDP (in national currency) and real GDP growth come from the IMFs World Economic Outlook (WEO) database, which covers 189 countries starting in 1980. For robustness purposes, we also use an indicator of the fiscal stance based on government's consumption forecasts errors, retrieved from the October vintage of the WEO forecasts. Actual data on government consumption correspond to the first release. Summary statistics for our panel of 55 developing countries are presented in the Appendix Table A.1. The list of financial crises by type and country is displayed in the appendix Table A2.

\section{Results}

\section{a. Baseline}

Figure 1 plots the results obtained by estimating equation (1) for our six types of financial crises and for the four components of production-based GHG, namely $\mathrm{CO} 2, \mathrm{~N} 2 \mathrm{O}, \mathrm{CH} 4$ and F-gas. Financial crises seem to lead to a statistically significant reduction in $\mathrm{CO} 2$ emissions. The fall in $\mathrm{CO} 2$ emissions is sizeable when non-systemic crises take place. Looking at different types of crises, $\mathrm{CO} 2$ emissions also respond negatively and significantly following banking crises, while 
methane and fluorinated gas emissions react positively and significantly following debt crises and currency crises, respectively. Systemic crises also lead to a significant fall in fluorinated gas emissions.

[insert Figure 1]

Do production-based emissions behave differently from consumption-based ones? To provide an answer, equation (1) is re-estimated once more for these two dependent variables separately. Results are shown in Figure 2: systemic crises lead to a positive and statistically significant response from consumption-based emissions which suggests that this type of crises encourages the consumption of goods with a lower environmental quality. In contrast, productionbased emissions increase following debt crises. All other crises lead to statistically insignificant results as evidenced by confidence bands above and below zero.

[insert Figure 2]

From this point onwards, only those IRFs yielding statistically significant results are shown for reasons of parsimony (the full set of results is available from the authors upon request). The previous set of unconditional results mask, however, considerable variation depending on business cycle conditions, as shown by the estimation of equation (2) reported in Figure 3.

During periods of slack, financial crises in general seem to have a positive and statistically significant impact on both methane and nitrous oxide emissions. The reverse is true in good times 
for methane. Systemic crises that hit a country undergoing economic difficulties are associated with larger $\mathrm{CO} 2$ and both production-based and consumption-based GHG emissions. As for the type of financial crisis that seems to have larger impacts, debt crises are associated with increases in production-based GHG emissions irrespectively of the phase of the business cycle. Also, methane, F-gas and nitrous oxide react positively in the short to medium-run following debt crises that take place during bad economic times. Under strong economic conditions however, the effects tend to be negative but are most of the times not very precisely estimated.

We also redid the previous analysis by focusing instead on economic sectors instead of gas nature. Such results are displayed in Figure A1 in the Appendix. They show that when hit by a debt crisis, a country experiences a rise in emissions stemming from either energy related activities or industrial processes. These effects are potentially large in the medium term and statistically different from zero. In addition, relying on longer CO2 series, Figure A2 shows that carbon dioxide emissions emanating from manufacturing (transportation) decrease (increase) following a financial/banking (systemic) crisis. CO2 stemming from other fuel combustion reacts positively and statistically significantly following a systemic or debt crisis.

\section{[insert Figure 3]}

Next, we split between emerging markets and low-income countries. Re-estimating equation (1) separately for each sub-sample yields the results displayed in Figures 4 and 5. In Figure 4, we observe that financial (debt) crises result in a fall in CO2 (production-based GHG) emissions in emerging market economies in normal times. When we condition by the state of the economy (not shown for reasons of parsimony), most types of crises are associated with a rise in 
emissions from $\mathrm{CO} 2$ and production based GHG during periods of economic slack, but they tend to decline during booms (despite this effect being less precisely estimated on average). Evidence seems to suggest that in bad times, emerging market economies do not take that opportunity to get away from carbon-intensive technologies and invest in cleaner ones, contrary to Papandreou's (2015) argument. In Figure 5, the unconditional results for low-income countries show positive (negative) and statistically significant response of methane following banking (currency) crises. Estimating equation 2 for the subsample of low-income countries (not shown for reasons of parsimony) shows a rise (fall) in methane emissions during bad times following banking and debt (systemic) crises. In periods of strong economic conditions, most IRFs are not statistically different from zero (except the negative association between methane emissions and debt crises).

[insert Figure 4]

[insert Figure 5]

\section{b. Sensitivity and Robustness checks}

\section{Sensitivity}

A possible bias from estimating equation (1) using country-fixed effects is that the error term may have a non-zero expected value, due to the interaction of fixed effects and country-specific developments (Tuelings and Zubanov, 2010). This would lead to a bias of the estimates that is a function of $k$. To address this issue, equation (1) was re-estimated by excluding country fixed effects from the analysis. Results (not shown but available upon request) suggest that this bias is negligible. 
As an additional sensitivity check, equation (1) was re-estimated for different lags (1) of the variables in the $\mathrm{X}$ vector. Results for zero lags, one lag and three lags (not shown but available upon request) confirm that previous findings are not sensitive to the choice of the number of lags.

\section{Robustness to the identification of slack}

We employed an output gap measure as an alternative proxy to measure the economic slack entering the function $F\left(z_{i t}\right)$ that is present in equation (2). There isn't a widely accepted approach to calculate potential output. Two alternative approaches are typically used (Borio, 2013): i) there are univariate statistical approaches, which consist of filtering out the trend component from the cyclical one; ii) there are the structural approaches, which derive the estimates directly from the theoretical structure of a model. Aware of the shortcomings of using either one or the other, we apply the recent filtering technique developed by Hamilton (2018). We are also mindful of the criticisms surrounding the popular use of the Hodrick-Prescott (HP) filter (such as the identification of spurious cycles) in the context of a very large heterogeneous sample (Harvey and Jaeger, 1993; Cogley and Nason, 1995). Hamilton's (2018) method to extract the cyclical and trend component of a generic variable $x_{t}$ (denoted $x^{c}{ }_{t}$ and $x^{\tau}{ }_{t}$, respectively), consists of estimating the following:

$x_{t+h}=\gamma_{0}+\sum_{j=0}^{k} \gamma_{j}+x_{t-j}+u_{t+h}$

where $x_{t}=x^{\tau}{ }_{t}+x^{c}{ }_{t}$.

The non-stationary part of the regression provides the cyclical component:

$x_{t}^{c}=\widehat{u_{t}}$

while the trend is given by 
$x_{t}^{\tau}=\widehat{\gamma_{0}}+\sum_{j=0}^{k} \widehat{\gamma_{j}}+x_{t-h-j}$

Hamilton (2018) suggests that $h$ and $k$ should be chosen such that the residuals from equation (3) are stationary and points out that, for a broad array of processes, the fourth differences of a series are indeed stationary. We choose $h=2$ and $k=3$, which is line with the dynamics seen in real GDP. Results of re-estimating equation 2 using the newly computed output gap as measure of slack, are displayed in Figure A3 in the Appendix. We can see that while there are some similarities, there are also some insightful differences with respect to the IRFs presented in Figure 3. $\mathrm{CO} 2$ emissions decline in times of economic strain after a financial crisis (particularly nonsystemic and banking ones). Moreover, production-based GHG emissions always reactive positively and significantly following a debt crisis irrespectively of the state of the economy. Finally, methane and nitrous oxide emissions increase after a debt crisis that hits the economic during periods of slack.

\section{Does the prevailing fiscal stance matter?}

The response of emissions to financial crises may also depend on whether the government is engaging in expansionary or contractionary fiscal policy at the time the economy is hit. To our knowledge, the only paper relating fiscal policy and the environment is the one by Lopez, Galinato and Islam (2011). The authors model (and empirically test) the impact of fiscal spending patterns on the environment and find that there is a reallocation of government spending composition towards social and public goods that tend to reduce pollution when an economy is hit by a negative shock. They further conclude that increasing total government spending (that is, engaging in expansionary fiscal policy) without altering its composition, does not reduce polluting emissions. 
while our setting is not identical, we still aim to shed further light into the effects of crises on the environment conditioning on prevailing (at the time of the shock) fiscal conditions.

We consider an alternative version of equation (2) where instead of the state of the economy, we use an indicator of fiscal policy stance. The fiscal policy stance indicator is a government consumption shock, identified as the forecast error of government consumption expenditure relative to GDP (for a similar approach see Auerbach and Gorodnichenko 2012, 2013; Abiad, Furceri, and Topalova 2015). ${ }^{11}$ Here, $\delta=1$ is used to assess the role of the fiscal policy. ${ }^{12}$ Figure 6 shows the results. Financial crises hitting an economy when it is engaging in contractionary fiscal policies, leads to a negative and statistically significant response of $\mathrm{CO} 2$ emissions. In contrast, after systemic (non-systemic) crises that take place in periods of fiscal relaxation, productionbased $\mathrm{GHG}(\mathrm{CO} 2)$ emissions go up (down) in the medium term. Furthermore, $\mathrm{CO} 2$ emissions react positively (negatively) after a banking or debt crisis concomitant with a loosening (tightening) of the fiscal stance. Finally, currency crises that take place at times of fiscal retrenchment lead to a fall in both $\mathrm{CO} 2$ and production based GHG emissions.

\section{[insert Figure 6]}

\section{Conclusion}

This paper provided empirical evidence on the impact of different types of financial crises on emissions in a panel of 55 countries from 1980 until 2012. Methodologically, we estimated

\footnotetext{
${ }^{11}$ This procedure also overcomes the problem of fiscal foresight (Forni and Gambetti 2010; Leeper et al., 2013; Ben Zeev and Pappa 2014), because it aligns the economic agents' and the econometrician's information sets.

${ }^{12}$ The results do not qualitatively change for different values of $\delta>0$.
} 
impulse response functions of a variety of emissions categories to financial crises using Jorda's (2005) local projection method.

We found that financial crises are associated with a statistically significant reduction in $\mathrm{CO} 2$ emissions. $\mathrm{CO} 2$ emissions also respond negatively and significantly following banking crises, while methane and fluorinated gas emissions react positively and significantly following debt crises and currency crises, respectively. Evidence points to the fact that systemic crises seem to lead to a positive and statistically significant response from consumption-based emissions, suggesting that this type of crises encouraged the consumption of goods with a lower environmental quality. In contrast, production-based emissions rose following debt crises. Furthermore, a country experiences a rise in emissions stemming from either energy related activities or industrial processes when hit by a debt crisis.CO2 emissions emanating from manufacturing (transportation) decrease (increase) following a financial/banking (systemic) crisis. During bad times, financial crises in general had a positive and statistically significant impact on both methane and nitrous oxide emissions. In contrast, during good times, the effects tend to be negative but are most of the times not very precisely estimated. If a financial crisis hit an economy when it is consolidating its public finances, this led to a negative and statistically significant response of $\mathrm{CO} 2$ emissions. After systemic (non-systemic) crises that take place in periods of fiscal relaxation, production-based GHG (CO2) emissions go up (down) in the medium term. Finally, currency crises that take place at times of fiscal retrenchment lead to a fall in both $\mathrm{CO} 2$ and production based GHG emissions.

For policy makers, it is important so see financial crises as opportunities to make big reductions in emissions that one can then lock in, and ensure that carbon prices, investments and other policies 
nudge us all toward innovations that, in turn, give the tools to be a low carbon society, with a business model that combines prosperity with responsibility. 


\section{References}

1. Abiad, A., Furceri, D., Topalova, P. (2015), "The Macroeconomic effects of public investment: evidence from Advanced Economies", IMF WP 15/95. Washington DC.

2. Acemoglu, D. and J. Robinson (2012), "Why Nations Fail: The origins of power, prosperity and Poverty", Crown Business

3. Ajmi, A., S. Hammoudeh, D. Nguyen, and J. Sato. (2015). "On the Relationships between CO2 Emissions, Energy Consumption and Income: The Importance of Time Variation". Energy Economics 49, 629-38.

4. Amann, M., Cofala, J., Rafaj, P, Wagner, F. (2009), "The Impact of the economic crises on GHG mitigation and costs in Annex I countries", International Institute for Applied Systems Analysis.

5. Auerbach, A., and Y. Gorodnichenko (2012), "Fiscal Multipliers in Recession and Expansion." In Fiscal Policy After the Financial Crisis, eds. Alberto Alesina and Francesco Giavazzi, NBER Books, National Bureau of Economic Research, Inc., Cambridge, Massachusetts. 6. Auerbach, A., and Y. Gorodnichenko (2013), "Measuring the Output Responses to Fiscal Policy." American Economic Journal: Economic Policy 4 (2), 1-27.

7. Ball, L. Furceri, D., Leigh, D., Loungani, P. (2013), "The distributional effects of fiscal consolidation", IMF WP 13/151, Washington DC.

8. Ben Zeev, N., and E. Pappa (2014), "Chronicle of a War Foretold: The Macroeconomic Effects of Anticipated Defense Spending Shocks." CEPR Discussion Paper 9948, Centre for Economic Policy Research, London.

9. Caprio, G. and D. Klingebiel, L. Laeven and G. Noguera (2005), "Banking Crisis

Database," In Patrick Honohan and Luc Laeven (eds.), Systemic Financial Crises, Cambridge:

Cambridge University Press.

10. Cogley, T. and J. Nason (1995), "Effects of the Hodrick-Prescott filter on trend and difference stationary time series Implications for business cycle research," Journal of Economic Dynamics and Control, 19(1-2), 253- 278.

11. Cohen, G., Jalles, J., Marto, R., Loungani, P. (2018)" The Long-Run Decoupling of Emissions and Output: Evidence from the Largest Emitters", Energy Policy, 118(c), 58-68

12. Declercq, B., Delarue, E. and D`haeseleer, W. (2011), "Impact of the economic recession on the European power sector's CO2 emissions". Energy Policy, 39, 1677-1686.

13. Del Río, P.and Labandeira, X. (2009), "Climate change at times of economic crisis", FEDEA Coleccion Estudios Economicos, 05-09.

14. Doda, B. (2014), "Evidence on Business Cycles and CO2 Emissions". Journal of Macroeconomics 40, 214-227

15. Egenhofer, C. (2008), "Climate change policy after the financial crisis: The latest excuse for a new round of state aid?", CEPS Commentary/30 October 2008, Brussels

16. Enkvist, P. A., Dinkel, J., and Lin, C. (2010), "Impact of the financial crisis on carbon economics: Version 2.1 of the global greenhouse gas abatement cost curve", McKinsey \& Company.

17. Forni, M., and L. Gambetti (2010), "Fiscal Foresight and the Effects of Government Spending.” CEPR Discussion Paper 7840, Centre for Economic Policy Research, London. 
18. Geels, F. (2013), "The impact of the financial-economic crisis on sustainability transitions: financial investment, governance and public discourse", Environmental Innovation and Societal Transitions, 6, 67-95.

19. Geels, F. W. (2002), "Technological transitions as evolutionary reconfiguration processes: a multi-level perspective and a case-study", Research Policy, 31(8), 1257-1274.

20. Gierdraitis, V., Girdenas, S., and Rovas, A. (2010), "Feeling the heat: Financial crises and their impact on global climate change", Perspectives of Innovations, Economics and Business, $4(1), 7-10$.

21. Granger, C. W. J., and T. Teräsvirta (1993), "Modelling Nonlinear Economic Relationships". New York: Oxford University Press.

22. Greenpeace (2008), "Energy[r]evolution. A Sustainable EU-27 Energy Outlook". Greenpeace International. November 2008.

23. Hamilton, J. (2018), "Why You Should Never Use the Hodrick-Prescott Filter," Review of Economics and Statistics, 100(5), 831-843.

24. Harvey, A. and A. Jaeger (1993), "Detrending, Stylized Facts and the Business Cycle," Journal of Applied Econometrics, 8(3), 231-47.

25. Hordijk, L. and M. Amann (2007), "How Science and Policy Combined to Combat Air Pollution Problems", Environmental Policy and Law, 37(4), 336-340.

26. IEA. (2013). Tracking clean energy progress 2013. International Energy Agency.

27. Jaunky, V. C. (2010), "The CO2 emission-income nexus: Evidence from rich countries". Energy Policy, 39, 1228-1240.

28. Jordà, O. (2005), "Estimation and Inference of Impulse Responses by Local Projections." American Economic Review 95 (1), 161-82.

29. Kaika, D. and Zervas, E. (2013a). The Environmental Kuznets Curve (EKC) theory — Part A: Concept, causes and the CO2 emissions case. Energy Policy 62, 1392-1402.

30. Kaika, D. and Zervas, E. (2013b). The Environmental Kuznets Curve (EKC) theory - Part B: Critical issues. Energy Policy 62, 1403-1411.

31. Kriström, B. and T. Lundgren (2005), "Swedish CO2 Emissions 1900-2100 - An Exploratory Note", Energy Policy, 33, 1223-1230.

32. Laeven, Luc and Fabian Valencia, 2010, "Resolution of Banking Crises: The Good, the Bad, and the Ugly," IMF Working Paper No. 10/44.

33. Lane, J.-E. (2011), "CO2 emissions and GDP”. International Journal of Social Economics, 38, $911-918$.

34. Leeper, E. M., T. B. Walker, and S. S. Yang (2013), "Fiscal Foresight and Information Flows." Econometrica 81 (3), 1115-1145.

35. Leichenko, R. M., O'Brien, K. L., and Solecki, W. D. (2010). Climate Change and the Global Financial Crisis: A Case of Double Exposure. Annals of the Association of American Geographers, 100, 963-972.

36. Marechal, K. (2007), "The economics of climate change and the change of climate in economics", Energy Policy, 35, 5181-5194.

37. Peters, G. P., and E. G. Hertwich (2008), "CO2 embodied in international trade with implications for global climate policy", Environmental Science Technology, 42, 1401-1407

38. Peters, G. P., Marland, G., Le Quéré, C., Boden, T., Canadell, J. G., and Raupach, M. R. (2011), "Rapid growth in CO2 emissions after the 2008-2009 global financial crisis". Nature Climate Change, 2(1), 2-4. 
39. Siddiqi, T. A. (2000), "The Asian Financial Crisis: is it good for the global environment?", Environmental Change, 10, 1-7.

40. Sobrino, N., and Monzon, A. (2014), "The impact of the economic crisis and policy actions on GHG emissions from road transport in Spain", Energy Policy, 74, 486-498.

41. Stavytskyy, A., Giedraitis, V., Sakalauskas, D., and Huettinger, M. (2016), "Economic crises and emission of pollutants: a historical review of selected economies amid two economic recessions", Ekonomia, 95(1).

42. Stern, D. I. (2004), "The rise and fall of the environmental Kuznets curve", World Development. 32 (8), 1419-1439.

43. Teulings, C., and N. Zubanov (2010), "Economic Recovery a Myth? Robust Estimation of Impulse Responses," CEPR Discussion Paper 7300 (London: CEPR).

44. Tuinstra, W. (2007), "Preparing for the European Thematic Strategy on air pollution: at the interface between science and policy", Environmental Science and Policy 10(5), 434- 444.

45. Unruh, G., (2000), "Understanding carbon lock-in". Energy Policy 28, 817-830.

46. Van Bree, B., Verbong, G.P.J., Kramer, G. J. (2010), "A multi-level perspective on the introduction of hydrogen and battery-electric vehicles". Technological Forecasting and Social Change 77, 529-540

47. Wooders, P. and Runnals, D. (2008), "The Financial Crisis and Our Response to Climate Change". An IISD Commentary.

48. York R. (2012), "Asymmetric effects of economic growth and decline on CO2 emissions", Nature Climate Change. 2(11), 762-764. 


\section{APPENDIX}

\section{LIST OF COUNTRIES}

Turkey, South Africa, Argentina, Bolivia, Brazil, Chile, Colombia, Haiti, Honduras Mexico, Nicaragua, Peru, Jordan, Egypt, Yemen, Bangladesh, Cambodia, India, Indonesia, Lao P.D.R., Nepal, Pakistan, Philippines, Thailand, Vietnam, Cameroon, Chad, Congo, Rep., Congo, Dem. Rep., Ethiopia, Ghana, Côte d'Ivoire, Kenya, Madagascar, Mali, Morocco, Mozambique, Nigeria, Sudan, Tanzania, Uganda, Burkina Faso, Zambia, Kazakhstan, Bulgaria, Moldova, Russia, Tajikistan, China, Ukraine, Uzbekistan, Hungary, Lithuania, Poland, Romania

Table A1. Summary Statistics, developing countries

\begin{tabular}{l|ccccc}
\hline Variable & Observations & Mean & Standard Deviation & Min & Max \\
\hline financial crises & 1540 & 0.101 & 0.300 & 0 & 1 \\
systemic crises & 1540 & 0.044 & 0.206 & 0 & 1 \\
non-systemic crises & 1540 & 0.192 & 0.394 & 0 & 1 \\
banking crises & 1540 & 0.038 & 0.193 & 0 & 1 \\
currency crises & 1540 & 0.051 & 0.221 & 0 & 1 \\
debt crises & 1540 & 0.021 & 0.142 & 0 & 1 \\
real GDP growth & 2939 & 2.971 & 6.422 & -69.70 & 53.810 \\
CO2 & 3431 & 91.378 & 449.111 & 0.018 & 9019.518 \\
production based GHG & 2643 & 163.631 & 672.239 & 0.035 & 10975.5 \\
consumption based GHG & 2503 & 140.713 & 562.701 & 0.01 & 9337.216 \\
CH4 & 2611 & 38.518 & 102.825 & 0.011 & 914.002 \\
N2O & 2611 & 15.684 & 45.919 & 0.002 & 572.44 \\
F-gas & 2645 & 1.604 & 10.19 & 0 & 182.314 \\
emissions from energy & 1993 & 154.015 & 600.817 & 0.742 & 8649.794 \\
emissions from industrial processes & 2538 & 9.379 & 61.880 & 0 & 1296.546 \\
emissions from agriculture & 2611 & 30.955 & 89.666 & 0.005 & 844.54 \\
emissions from waste & 2645 & 7.259 & 20.919 & 0.003 & 197.6 \\
CO2 from electricity and heat & 2697 & 52.852 & 249.470 & 0 & 4404.92 \\
CO2 from manufacturing & 2697 & 30.990 & 157.860 & 0 & 2546.06 \\
CO2 from transportation & 2697 & 16.073 & 44.867 & 0.04 & 702.91 \\
CO2 from other fuel combustion & 2697 & 14.604 & 53.228 & 0 & 551.97 \\
\hline Not all & & & & & \\
\hline
\end{tabular}

Note: all emissions expressed in $\mathrm{MtCO} 2 \mathrm{e}$. 


\section{Table A2. List (years) of Crises by type (from Laeven and Valencia, 2010 updated)}

\begin{tabular}{|c|c|c|c|c|c|c|}
\hline Country & Financial crisis & $\begin{array}{l}\text { Systemic } \\
\text { crisis }\end{array}$ & Non-systemic crisis & Banking crisis & Currency crisis & $\begin{array}{l}\text { Debt } \\
\text { crisis }\end{array}$ \\
\hline Turkey & $\begin{array}{l}1982,1984,1991,1996, \\
2000,2001\end{array}$ & & $1982,1984,2000,2001$ & 1982,2000 & $\begin{array}{l}1984,1991, \\
1996,2001\end{array}$ & \\
\hline South Africa & 1984,1985 & & & & 1984 & 1985 \\
\hline Argentina & $\begin{array}{l}1980,1981,1982,1987 \\
1989,1995,2001,2002\end{array}$ & & $\begin{array}{l}1980,1981,1982,1989, \\
1995,2001,2002\end{array}$ & $\begin{array}{l}1980,1989 \\
1995,2001\end{array}$ & $\begin{array}{l}1981,1987, \\
2002\end{array}$ & $\begin{array}{l}1982, \\
2001\end{array}$ \\
\hline Bolivia & $1980,1981,1986,1994$ & & 1986,1994 & 1986,1994 & 1981 & 1980 \\
\hline Brazil & $\begin{array}{l}1982,1983,1987,1990, \\
1992,1994,1999\end{array}$ & & $190,1994,1999$ & 1990,1994 & $\begin{array}{l}1982,1987, \\
1992,1999\end{array}$ & 1983 \\
\hline Chile & $1981,1982,1983$ & & $1981,1982,1983$ & 1981 & 1982 & 1983 \\
\hline Colombia & $1982,1985,1998$ & & 1982,1985 & 1982,1998 & 1985 & \\
\hline Haiti & $1992,1994,2003$ & & & 1994 & 1992,2003 & \\
\hline Honduras & 1981,1990 & & & & 1990 & 1981 \\
\hline Mexico & $1981,1982,1994,1995$ & & $1981,1982,1994,1995$ & 1981,1994 & 1982,1995 & 1982 \\
\hline Nicaragua & $1980,1985,1990,2000$ & & 1990,2000 & 1990,2000 & 1985,1990 & 1980 \\
\hline Peru & $1981,1983,1988$ & & 1983,1988 & 1983 & 1981 & 1988 \\
\hline Jordan & 1989 & 1989 & & 1989 & 1989 & 1989 \\
\hline Egypt & $1980,1984,1990$ & & 1980,1984 & 1980 & 1990 & 1984 \\
\hline Yemen & $1985,1995,1996$ & & 1996, & 1996 & 1985,1995 & \\
\hline Bangladesh & 1987 & & & 1987 & & \\
\hline Cambodia & 1992 & & & & 1992 & \\
\hline India & 1993 & 1993 & & 1993 & & \\
\hline Indonesia & $1997,1998,1999$ & & $1997,1998,1999$ & 1997 & 1998 & 1999 \\
\hline Laos & 1986,1997 & 1997 & & & 1986,1997 & \\
\hline Nepal & $1984,1988,1992$ & & 1988 & 1988 & 1984,1992 & \\
\hline Philippines & $1983,1997,1998$ & & 1983,1998 & 1983,1997 & 1983 & 1983 \\
\hline Thailand & $1983,1997,1998$ & & $1983,1997,1998$ & 1983,1997 & 1998 & \\
\hline Vietnam & $1981,1985,1987,1997$ & & & & 1981,1987 & 1985 \\
\hline Cameroon & $1987,1989,1994,1995$ & & $1987,1989,1995$ & 1987,1995 & 1994 & 1989 \\
\hline Chad & $1983,1992,1994$ & & 1983,1992 & 1983,1992 & 1994 & \\
\hline Congo & $\begin{array}{l}1983,1986,1989,1991, \\
1992,1994,1999\end{array}$ & & $\begin{array}{l}1983,1986,1989,1991, \\
1992,1994,1999\end{array}$ & $\begin{array}{l}1983,1991 \\
1992,1994\end{array}$ & $\begin{array}{l}1989,1994, \\
1999\end{array}$ & 1986 \\
\hline Ethiopia & 1993 & & & & 1993 & \\
\hline Ghana & $1982,1983,1993,2000$ & & 1982,1983 & 1982 & $\begin{array}{l}1983,1993, \\
2000\end{array}$ & \\
\hline Cote Ivoire & $1984,1988,1994,2001$ & & 1988 & 1988 & 1994 & $\begin{array}{l}1984, \\
2001\end{array}$ \\
\hline Kenya & $1985,1992,1993$ & & $1985,1992,1993$ & 1985,1992 & 1993 & \\
\hline Madagascar & $\begin{array}{l}1981,1984,1988,1994, \\
2004\end{array}$ & & 1988 & 1988 & $\begin{array}{l}1984,1994, \\
2001\end{array}$ & 1981 \\
\hline Mali & 1987,1994 & & 1987 & 1987 & 1994 & \\
\hline Morocco & $1980,1981,1983$ & & $1980,1981,1983$ & 1980 & 1981 & 1983 \\
\hline Mozambique & 1984,1987 & & 1987 & 1987 & 1987 & 1984 \\
\hline Nigeria & $1983,1989,1991$ & & 1991 & 1991 & 1983,1989 & 1983 \\
\hline Sudan & $1981,1988,1994$ & & & & $\begin{array}{l}1981,1988, \\
1994\end{array}$ & \\
\hline Tanzania & $1984,1985,1987,1990$ & & 1987,1990 & 1987 & 1985 & 1984 \\
\hline Uganda & $1980,1981,1988,1994$ & & 1994 & 1994 & 1980,1988 & 1981 \\
\hline $\begin{array}{l}\text { Burkina } \\
\text { Faso }\end{array}$ & 1990,1994 & & 1990,1994 & 1990 & 1994 & \\
\hline Zambia & $1983,1989,1995,1996$ & & 1995 & 1995 & $\begin{array}{l}1983,1989, \\
1995\end{array}$ & 1983 \\
\hline Kazakhstan & 1999 & & & & 1999 & \\
\hline Bulgaria & 1990,1996 & & 1996 & 1996 & 1996 & 1990 \\
\hline Moldova & 1999,2002 & & & & 1999 & 2002 \\
\hline Russia & 1998 & & 1998 & 1998 & 1998 & 1998 \\
\hline Tajikistan & 1999 & 1999 & & & 1999 & \\
\hline China & 1998 & & 1998 & 1998 & & \\
\hline Ukraine & 1998 & & 1998 & 1998 & 1998 & 1998 \\
\hline Uzbekistan & 1994,2000 & & & & 1994,2000 & \\
\hline Lithuania & 1992,1995 & & 1995 & 1995 & & 1992 \\
\hline Poland & 1981,1992 & & 1992 & 1992 & & 1981 \\
\hline Romania & $1982,1990,1996$ & & 1990,1996 & 1990 & 1996 & 1982 \\
\hline
\end{tabular}


